\title{
IMPACT OF FLOWBACK WATER ON ACTIVATED SLUDGE BIOCENOSIS DURING MUNICIPAL WASTEWATER TREATMENT
}

\author{
WPLYW WÓD PO SZCZELINOWANIU HYDRAULICZNYM NA BIOCENOZE \\ OSADU CZYNNEGO PODCZAS OCZYSZCZANIA ŚCIEKÓW MIEJSKICH
}

\begin{abstract}
The aim of this study was to determine the effect of flowback water on an activated sludge biocenosis during municipal wastewater treatment in the sequencing batch reactors (SBRs). Two series were performed. In series 1 , only municipal wastewater was treated, whereas in series 2, municipal wastewater with pre-treated flowback water was used. Flowback water constituted 3-5\% of the influent and was introduced to the SBRs twice per week. Introducing flowback water did not decrease the quality of effluent from the SBRs. However, the composition of the activated sludge biocenosis differed between series, ie the biodiversity of protozoa and the relative abundance of microfauna in functional groups changed after flowback water addition. Polymerase chain reaction - denaturing gradient gel electrophoresis (PCR-DGGE) showed that the ammonia oxidizers community responded faster to flowback water addition than the total bacterial community and remained relatively stable during treatment. However, after 9 weeks of exposure to flowback water, ammonia oxidizing bacteria (AOB) biodiversity decreased. This suggests that prolonged exposure could cause nitrification problems, leading to deterioration in effluent quality.
\end{abstract}

Keywords: flowback water, SBR, activated sludge microfauna, AOB community, PCR-DGGE

\section{Introduction}

Due to the industrial development new sources of fuel are necessarily to be found all over the world. Among them, shale gas seems to be promising source of energy. Shale gas, trapped within shale formations, has become an increasingly important source of natural gas in the United States and other Western European countries. Also Poland is more and more

\footnotetext{
${ }^{1}$ Environmental Biotechnology Department, Silesian University of Technology, ul. Akademicka 2, 44-100 Gliwice, Poland, phone +48 3223726 94; fax +48 322372946

${ }^{2}$ Department of Tourism, Recreation and Ecology, University of Warmia and Mazury in Olsztyn, ul. Oczapowskiego 5, 10-957 Olsztyn, Poland, phone +48 $8952451 \quad 07$, fax +48 $89523 \quad 3290$, email: adam.drzewicki@uwm.edu.pl

${ }^{3}$ Department of Environmental Biotechnology, University of Warmia and Mazury in Olsztyn, ul. Słoneczna 45G, 10-718 Olsztyn, Poland, phone/fax +48 8952341 45, email: dorotak@uwm.edu.pl

${ }^{*}$ Corresponding author: aleksandra.ziembinska-buczynska@polsl.pl
} 
interested in shale gas extraction. The first trials of shale gas extraction were undertaken in XIX century, but due to the low permeability of shales gas outflow from the drill was insufficient. Recently, due to modern technology development hydraulic fracturing (fracking) is used to create extensive artificial fractures around well bores.

Shale gas fracking produces dangerous effluent due to the usage of fracturing fluids (fracs) harmful to the environment. Hydraulic fracturing fluids consist of water that is mixed with solid elements (commonly sand) and chemicals. This mixture is injected into a well under high pressure (480 to 850 bars) to open existing fractures or make new fractures [1]. The sorts of chemicals used for this procedure are governed by the geological characteristics of each site and the chemical characteristics of the water used. It is known that many of the chemicals added for fracturing are not currently regulated by local law. In the USA from 2005 to 2009 , ca. 750 chemicals and other elements were used in frac waters, ranging from harmless components (coffee grounds or walnut hulls) to others that may be hazardous if introduced into the water supply [2]. Fracturing water can also contain inorganic acids (used for cleaning the well bore area after perforation and dissolving soluble minerals) and organic compounds (used to reduce friction between the fluid and the wellbore, in order to lower the pumping costs) [1].

Between 10 to $90 \%$ of fracking fluids return to the surface [3] and it is known that flowback water characteristics vary from one gas field to another. Hence, two or more treatment systems should be used in series, as a single technology cannot create suitable effluent composition. From a paper written by Olsson et al [4], it is known that in Germany, flowback water is currently treated by separating particulate matter using hydro-cyclones, sedimentation of removable substances, skimming off lightweight substances in separation and storage tanks and filtration systems. According to Fakhru'l-Razi et al [5] physical, chemical and biological methods can be used to treat flowback water. However, each method of such treatment has advantages and disadvantages. The authors stated that the disadvantages of physical methods are the high initial capital costs and sensitivity to the variable characteristics of flowback water. In case of chemical treatment the problem is the generation of hazardous sludge that needs to be treated and disposed. For biological treatment the sensitivity to variation of organic chemicals and salt concentrations of the influent could be a problem [4 after 5]. However, Olsson et al [4] suggest that biological treatment of flowback water may be effective with water that contains organic compounds and has a low salt content $\left(<10 \mathrm{~g} \cdot \mathrm{dm}^{-3}\right)$. So far the effect of flowback water on the activated sludge microorganisms involved in wastewater treatment has not been determined. For this reason, it is necessary to perform studies that examine how the composition of activated sludge biocenoses, bacterial communities and the effectiveness of wastewater treatment change with exposure to flowback water.

Activated sludge is formed mainly with bacteria, and also include protozoa, rotifers, and nematodes, and less commonly, larger invertebrates and fungi. In these artificial ecosystems, protozoa are the primary consumers of bacteria and fungi as well as food sources for metazoa, constructing an essential trophic link in the food web and making a numerically and functionally significant contribution [6]. The presence of toxic substances in the influent may induce changes in the feeding structure of an activated sludge ecosystem, thus affecting its activity and the biological performance of the wastewater treatment plant. 
In microfauna communities, protozoa is usually one of the major groups. According to several reports, protozoa are considered to be an important bioindicators of the activated sludge process and, specifically, indicators of the presence of toxic compounds.

For last 30 years, the development of bacterial ecology has been supported with molecular biology tools. Polymerase chain reaction - denaturing gradient gel electrophoresis (PCR-DGGE) is considered to be the most useful for monitoring changes in bacterial communities. Within the community, it is possible to monitor the variability of bacterial functional subgroups, such as nitrifiers or denitrifiers. Among activated sludge bacteria, ammonia oxidizing bacteria (AOB), which perform the first phase of nitrification, are known to be good indicators of harmful substance presence in the wastewater. They respond quickly due to their high sensitivity to physic-chemical changes.

There is positive relationship between microbial diversity in activated sludge and effectiveness of wastewater treatment [7]. However, to the best of our knowledge, there have been no studies that monitored bacterial and protozoan populations in activated sludge during co-treatment of municipal wastewater with flowback water to assess possible relationships between the microbial communities and treatment effectiveness. Therefore, the aim of this study was to estimate the effect of flowback waters on: I) wastewater treatment efficiency in a municipal wastewater treatment plant (WWTP) working as the sequencing batch reactors (SBRs), and II) on activated sludge microorganisms and bacterial communities by using microscopic and molecular techniques, respectively. The latter are particularly useful to assess the condition of the activated sludge and the proper functioning of the WWTP.

\section{Materials and methods}

\section{Characteristics of the WWTP}

The WWTP where the experiment was performed was designed for an average daily flow rate of wastewater of $4200 \mathrm{~m}^{3} \cdot \mathrm{d}^{-1}$ and works with a mechanical-biological system. The mechanical stage contains a coarse screen (with a grid size of $2 \mathrm{~mm}$ ), and a grit chamber, whereas the biological stage comprises 3 SBRs, working in parallel, with a total volume of $1740 \mathrm{~m}^{3}$. The volumetric exchange rate, defined as the ratio of the volume of wastewater supplied to the reactor in a cycle to the working volume, was 0.5 . The WWTP was operated with the following technological parameters: MLSS $5120 \pm 312 \mathrm{mg} \cdot \mathrm{dm}^{-3}$; MLVSS $3940 \pm 240 \mathrm{mg} \cdot \mathrm{dm}^{-3}$; DO during aeration phase of $3-4 \mathrm{mg} \cdot \mathrm{dm}^{-3}$; DO during anoxic phase about $0.5 \mathrm{mg} \cdot \mathrm{dm}^{-3}$, and a SRT of $22 \pm 3 \mathrm{~d}$. The SBRs were operated in a $12 \mathrm{~h}$ cycle. Each cycle consisted of the four phases: filling/mixing $(4 \mathrm{~h})$, aeration $(4.5 \mathrm{~h})$, settling $(2 \mathrm{~h})$ and decantation $(1.5 \mathrm{~h})$.

The WWTP was supplied with municipal wastewater (series 1), and mixture of municipal wastewater with water from the hydraulic fracturing of shale gas (flowback water) (series 2). Flowback water constituted 3-5\% of the influent and was introduced to the SBRs 2 times a week.

The flowback water was pretreated via physico-chemical methods (disinfection, coagulation and flocculation) at the place of shale gas extraction. Sodium chlorate, calcium hydroxide, ferric sulphate and polyelectrolytes were used for pre-treatment. After coagulation, the content of the chamber was discharged to a clarifier for sedimentation. 
Pretreated flowback water was then mixed with municipal wastewater for treatment in the WWTP.

Within the study period (12 weeks), for chemical analyses 24 samples were collected: 6 from series 1 , and 18 from series 2 . Samples were collected twice a week.

\section{Analytical methods}

For both raw and treated wastewater, the following characteristics were determined: $\mathrm{pH}$ (pH-meter HI 8818), chemical oxygen demand (COD), following Standard Methods [8], biochemical oxygen demand (BOD), using an OxiTop (WTW) following the official EPA method DIN EN 1899-1/EN 1899-2, as well as Kjeldahl nitrogen, ammonia-N, nitrite-N and nitrate-N, total phosphorus, total suspended solids and volatile suspended solids [8].

In flowback water, apart from the basic indicators of pollution mentioned above, metal content, chlorides, sulphur and fluorides were also determined (Table 1). These parameters were analyzed in specialized laboratory which meets requirements of the Polish standards.

\section{Identification of microfauna}

Samples for the identification of protozoa and small metazoa were collected from mixed liquor of the SBR reactors during their aeration phase. Samples were collected twice a week. The composition of the microfauna in the activated sludge was determined in vivo according to $[9,10]$ using phase contrast microscopy (Zeiss) at $100 \times-400 \times$ magnification, depending on the size of each taxon. The abundance of flagellates was estimated along the diagonal of a Fuchs-Rosenthal chamber [11]. To determine the abundance of other protozoa and metazoans, four $0.025 \mathrm{~cm}^{3}$ subsamples of mixed liquor were taken with a gravimetrically calibrated automatic micropipette. Then, the arithmetic average of the values obtained from each individual sample was calculated. Finally, the abundance of individual taxa was counted in $1 \mathrm{~cm}^{3}$ of activated sludge. The Sludge Biotic Index (SBI) has been determined using the method given by Madoni [11]. For estimation of protist diversity, the Shannon Index $(\mathrm{H})$ was used. All biological identifications were finished within 3 hours after sample collection.

\section{DNA isolation and PCR-DGGE monitoring of activated sludge bacterial biocenosis}

Activated sludge samples (volume of $100 \mathrm{~cm}^{3}$ ) were collected from both series (before and during flowback water treatment; 5 samples in total) from technological installation at 2-week intervals and stored at $-20^{\circ} \mathrm{C}$ until DNA isolation.

Total genomic DNA was extracted from $0.2 \mathrm{~g}$ of the activated sludge samples using mechanical method. The samples were washed three times with $1 \times$ PBS buffer (Sigma) and disintegrated with bead beating (Roth, Germany) in lysis buffer (Tris-HCl, $100 \mathrm{mM}$, EDTA $100 \mathrm{mM}, \mathrm{NaCl} 1.5 \mathrm{M} ; \mathrm{pH}=8.0$ ). The samples were incubated 20 minutes in $1400 \mathrm{rpm}$ and $200 \mathrm{~mm}^{3} 10 \%$ SDS was added. After 30 minutes of incubation in $65^{\circ} \mathrm{C}$ samples were centrifuged twice at $13000 \mathrm{rpm}$ and placed on spin filters (A\&A Biotechnology). DNA attached to the filter was washed twice with $70 \%$ ethanol solution (A\&A Biotechnology). The amount of DNA was measured spectrophotometrically using Qubit (Invitrogen) and stored at $-20^{\circ} \mathrm{C}$ until PCR amplification.

Partial 16S rRNA gene amplification of all the bacteria was performed using primers: 338f-GC and 518r gene fragment [12]. AmoA gene was amplified with primers: Amof-GC 
and Amo2R-TC [13]. PCR reaction was performed in $30 \mathrm{~mm}^{3}$ mixture with $1.5 \mathrm{U}$ GoTAQ flexi Polymerase (Promega), $1 \times$ buffer, $2 \mathrm{mM} \mathrm{MgCl}$, $5 \mathrm{pmol} \cdot \mathrm{mm}^{-3}$ of each primers and $20 \mathrm{pmol} \cdot \mathrm{mm}^{-3}$ of dNTPs. Total bacteria DNA from activated sludge samples was used as DNA template. The amplification was performed in termocycler T-1000 (Bio-Rad) as previously described $[12,13]$. The PCR products were separated in $0.8 \%(\mathrm{w} / \mathrm{v})$ agarose with ethidium bromide in $1 \times \mathrm{TBE}$ buffer and visualized under UV light.

The DGGE of the PCR products obtained in reactions with $338 \mathrm{~F}-\mathrm{GC} / 518 \mathrm{R}$ and Amof-GC/Amo2R-TC primers underwent electrophoretic separation in the Dcode Universal Mutation Detection System (BioRad). Polyacrylamide gel (8\% for $16 \mathrm{~S}$ rRNA gene, 37:1 acrylamide-bisacrylamide, Fluka) with a gradient of 30-60\% denaturant was prepared according to the manufacturer's instruction. The gel was run for $16 \mathrm{~h}$ at $40 \mathrm{~V}$ in a $1 \times \mathrm{TAE}$ buffer at a constant temperature of $60^{\circ} \mathrm{C}$. The gel was stained with SYBR Gold (1:10 000, Invitrogen) in MiliQ water for $30 \mathrm{~min}$ and distained in MiliQ water for $40 \mathrm{~min}$, then visualized under UV light and photographed using Quantity One 1D (BioRad).

The analysis of DGGE fingerprints was performed using a Quantity One 1D software (BioRad). Bacterial biodiversity was estimated on the basis of densitometric measurements and Shannon diversity index as previously described [14].

\section{Statistical analyses}

Assuming the null hypothesis $\left(\mathrm{H}_{0}\right)$ that the average abundance of individuals in each taxon and the average number of taxa in the presence and absence of flowback water are the same, the Kruskal-Wallis test was used for statistical verification. The same test was used to verify $\mathrm{H}_{0}$ hypotheses that the average concentration of analyzed parameters in treated wastewater in both series was the same. The statistical significance of the relationship between protist diversity and the presence and absence of flowback water was assessed using Student's T-test [15]. Statistical analyses were performed using the STATISTICA 10 PL package for PCs.

\section{Results and discussion}

\section{Flowback water characteristics and their effect on municipal wastewater treatment efficiency}

Flowback water, the fluid that rises to the surface after hydraulic fracturing, comprises a mixture of hydraulic fracturing fluid, formation water, and condensed water that in turn contains hydraulic fracturing fluid and formation water $[4,16]$. Reports on the composition of flowback water show that it can vary from well to well. It consists extremely high concentrations of dissolved salts, therein $\mathrm{Na}^{+}$and $\mathrm{Cl}^{-}$, relatively high concentration of solid particles and lower concentration of total organic carbon (TOC) [17, 18].

The main constituents of the flowback water in this study and their concentrations are presented in Table 1.

It can be seen that the concentrations of most chemical indicators are lower than in other studies [17, 18]. Although there was a relatively high content of $\mathrm{Cl}^{-}$, $10600 \pm 8400 \mathrm{mg} \cdot \mathrm{dm}^{-3}$, it was from a few to several times lower than in other works $\left(28500 \mathrm{mg} \cdot \mathrm{dm}^{-3}\right.$ [18]; 16500-148000 $\mathrm{mg} \cdot \mathrm{dm}^{-3}$ [18]). Similarly, the concentration of total suspended solids was $89 \pm 18 \mathrm{mg} \cdot \mathrm{dm}^{-3}, 10$ times lower than in the work [17]. Interestingly, the flowback water in this study contains low concentrations of metals 
(Table 1) and relatively high concentrations of organics (COD $3369 \pm 2200 \mathrm{mg} \cdot \mathrm{dm}^{-3}$ ) and total nitrogen $\left(254 \pm 64 \mathrm{mg} \cdot \mathrm{dm}^{-3}\right)$.

Characteristics of flowback water $(n=11)$

Table 1

\begin{tabular}{|c|c|c|}
\hline Wastewater constituent & Unit & Value \\
\hline $\mathrm{pH}$ & - & $7.1 \pm 0.3$ \\
\hline COD & {$\left[\mathrm{mg} \cdot \mathrm{dm}^{-3}\right]$} & $3369 \pm 2200$ \\
\hline $\mathrm{BOD}_{5}$ & {$\left[\mathrm{mg} \cdot \mathrm{dm}^{-3}\right]$} & $214 \pm 43$ \\
\hline Total Kjeldahl nitrogen & {$\left[\mathrm{mg} \cdot \mathrm{dm}^{-3}\right]$} & $254 \pm 64$ \\
\hline Ammonium nitrogen & {$\left[\mathrm{mg} \cdot \mathrm{dm}^{-3}\right]$} & $14 \pm 17$ \\
\hline Nitrate nitrogen & {$\left[\mathrm{mg} \cdot \mathrm{dm}^{-3}\right]$} & $13.6 \pm 10.4$ \\
\hline Total phosphorus & {$\left[\mathrm{mg} \cdot \mathrm{dm}^{-3}\right]$} & $0.56 \pm 0.59$ \\
\hline Total suspended solids & {$\left[\mathrm{mg} \cdot \mathrm{dm}^{-3}\right]$} & $89 \pm 18$ \\
\hline $\mathrm{Cl}^{-}$ & {$\left[\mathrm{mg} \cdot \mathrm{dm}^{-3}\right]$} & $10600 \pm 8300$ \\
\hline $\mathrm{SO}_{4}{ }^{2-}$ & {$\left[\mathrm{mg} \cdot \mathrm{dm}^{-3}\right]$} & $692 \pm 293$ \\
\hline $\mathrm{F}^{-}$ & {$\left[\mathrm{mg} \cdot \mathrm{dm}^{-3}\right]$} & $0.55 \pm 0.06$ \\
\hline $\mathrm{Mn}$ & {$\left[\mathrm{mg} \cdot \mathrm{dm}^{-3}\right]$} & $4.1 \pm 2.8$ \\
\hline $\mathrm{Fe}$ & {$\left[\mathrm{mg} \cdot \mathrm{dm}^{-3}\right]$} & $28 \pm 17$ \\
\hline $\mathrm{Pb}$ & {$\left[\mathrm{mg} \cdot \mathrm{dm}^{-3}\right]$} & $0.029 \pm 0.006$ \\
\hline $\mathrm{Cd}$ & {$\left[\mathrm{mg} \cdot \mathrm{dm}^{-3}\right]$} & $0.0025 \pm 0.001$ \\
\hline $\mathrm{Cu}$ & {$\left[\mathrm{mg} \cdot \mathrm{dm}^{-3}\right]$} & $0.11 \pm 0.04$ \\
\hline $\mathrm{Zn}$ & {$\left[\mathrm{mg} \cdot \mathrm{dm}^{-3}\right]$} & $0.076 \pm 0.018$ \\
\hline $\mathrm{Cr}$ & {$\left[\mathrm{mg} \cdot \mathrm{dm}^{-3}\right]$} & $0.012 \pm 0.030$ \\
\hline $\mathrm{Hg}$ & {$\left[\mathrm{mg} \cdot \mathrm{dm}^{-3}\right]$} & $0.0005 \pm 0.0001$ \\
\hline $\mathrm{Ba}$ & {$\left[\mathrm{mg} \cdot \mathrm{dm}^{-3}\right]$} & $0.54 \pm 0.09$ \\
\hline $\mathrm{Ni}$ & {$\left[\mathrm{mg} \cdot \mathrm{dm}^{-3}\right]$} & $0.034 \pm 0.006$ \\
\hline As & {$\left[\mathrm{mg} \cdot \mathrm{dm}^{-3}\right]$} & $0.020 \pm 0.005$ \\
\hline $\mathrm{Se}$ & {$\left[\mathrm{mg} \cdot \mathrm{dm}^{-3}\right]$} & $0.020 \pm 0.004$ \\
\hline Mo & {$\left[\mathrm{mg} \cdot \mathrm{dm}^{-3}\right]$} & $0.003 \pm 0.006$ \\
\hline $\mathrm{Sb}$ & {$\left[\mathrm{mg} \cdot \mathrm{dm}^{-3}\right]$} & $0.002 \pm 0.004$ \\
\hline
\end{tabular}

The lower concentration of most indicators in the flowback water in this study is a result of its pretreatment at the place of shale gas extraction. Coagulation removes colloids and suspended solids, phosphorus, metals and radionuclides. Hence, the flowback water contained low concentrations of suspended solids, phosphorus and metals.

Table 2

Characteristics of raw and treated wastewater

\begin{tabular}{|c|c|c|c|c|c|}
\hline \multirow{2}{*}{ Wastewater constituent } & \multirow{2}{*}{ Unit } & \multicolumn{4}{|c|}{ Value $^{*}$} \\
\cline { 3 - 6 } & & \multicolumn{2}{|c|}{ series 1; $\boldsymbol{n}=\mathbf{6}$} & \multicolumn{2}{c|}{ series 2; $\boldsymbol{n}=\mathbf{1 8}$} \\
\cline { 3 - 6 } & & influent & effluent & influent & effluent \\
\hline $\mathrm{pH}$ & - & $7.56 \pm 0.28$ & $7.48 \pm 0.14$ & $7.33 \pm 0.49$ & $7.42 \pm 0.18$ \\
\hline $\mathrm{COD}$ & {$\left[\mathrm{mg} \cdot \mathrm{dm}^{-3}\right]$} & $930 \pm 260$ & $38.9 \pm 8.2$ & $1098 \pm 204$ & $37 \pm 10$ \\
\hline BOD & {$\left[\mathrm{mg} \cdot \mathrm{dm}^{-3}\right]$} & $407 \pm 120$ & $6.8 \pm 3.7$ & $397 \pm 139$ & $6.9 \pm 5.8$ \\
\hline Total Kjeldahl nitrogen & {$\left[\mathrm{mg} \cdot \mathrm{dm}^{-3}\right]$} & $76 \pm 16$ & $10.4 \pm 2.1$ & $90 \pm 23$ & $12.2 \pm 4.3$ \\
\hline Ammonium nitrogen & {$\left[\mathrm{mg} \cdot \mathrm{dm}^{-3}\right]$} & $57 \pm 15$ & $0.64 \pm 0.41$ & $59 \pm 12$ & $0.32 \pm 0.29$ \\
\hline Phosphorus & {$\left[\mathrm{mg} \cdot \mathrm{dm}^{-3}\right]$} & $7.6 \pm 4.2$ & $0.41 \pm 0.23$ & $7.1 \pm 3.9$ & $0.54 \pm 0.11$ \\
\hline Total suspended solids & {$\left[\mathrm{mg} \cdot \mathrm{dm}^{-3}\right]$} & $300 \pm 100$ & $10.4 \pm 6.4$ & $289 \pm 98$ & $13.6 \pm 7.2$ \\
\hline
\end{tabular}

$n$ - number of samples; * - all data are from WWTP working in technical scale 
In series 1 , without flowback water, the raw wastewater contained a relatively high amount of organic compounds (expressed as $\mathrm{BOD}_{5}$ and COD) and ammonia, amounting to $407 \pm 125 \mathrm{mg} \cdot \mathrm{dm}^{-3}, 930 \pm 260 \mathrm{mg} \cdot \mathrm{dm}^{-3}$ and $57.1 \pm 14.8 \mathrm{mg} \cdot \mathrm{dm}^{-3}$, respectively. Despite this, organics and nitrogen concentrations in the effluent did not exceed permissible values. $\mathrm{BOD}_{5}, \mathrm{COD}$ and suspended solids concentrations were $6.8 \pm 3.7 \mathrm{mg} \cdot \mathrm{dm}^{-3}$, $38.9 \pm 8.2 \mathrm{mg} \cdot \mathrm{dm}^{-3}$ and $10.4 \pm 6.4 \mathrm{mg} \cdot \mathrm{dm}^{-3}$, on average (Table 2).

Moreover, complete nitrification was obtained, and ammonia concentration in the effluent was below $1 \mathrm{mg} \cdot \mathrm{dm}^{-3}$. Phosphorus concentrations in raw and treated wastewater were $7.6 \pm 4.2 \mathrm{mg} \cdot \mathrm{dm}^{-3}$ and $0.41 \pm 0.23 \mathrm{mg} \cdot \mathrm{dm}^{-3}$, respectively. When flowback water was added in series 2, the concentrations of these indicators in both raw and treated wastewater did not change significantly (Kruskal-Wallis test, $p>0.05$ ). Interestingly, despite high concentrations of chlorides (Table 1), organics and nutrients were effectively removed.

From literature view it can be concluded that removal of organic compounds has not been found to be affected by even high concentrations of chlorides (up to $30.000 \mathrm{mg} \cdot \mathrm{dm}^{-3}$ ). In contrast, the effect of chlorides on nitrogen removal is not clear, but most studies show bacteria can acclimate to chlorides concentrations up to $10.000 \mathrm{mg} \cdot \mathrm{dm}^{-3}[19]$. Nitrifying bacteria are sensitive to chlorides concentrations above $10.000 \mathrm{mg} \cdot \mathrm{dm}^{-3}$; denitrifying bacteria have greater resistance to salinity. Phosphorus removal is more sensitive to changes in salinity. It has been found [20] that increasing wastewater salinity from 0 to $6 \%$ decreased phosphorus removal efficiency from 84 to $22 \%$, and observed high inhibition at a salinity of only $0.5 \%$. Similarly, [19] noted a decrease in phosphorus removal efficiency (about $50 \%$ ) at a chlorides concentration of $2000 \mathrm{mg} \cdot \mathrm{dm}^{-3}$. In our study, the removal efficiency of all these indicators did not decrease (Table 2). This was possibly connected with the relatively low share of flowback water in the influent (from 3 to $5 \%$ of the wastewater flow) and the volumetric exchange rate (0.5). Both of them caused low concentration of chlorides at the beginning of the SBR.

\section{Microfauna community}

During the research period the number of taxa varied from 13 to 17 (series 1, municipal wastewater) and from 13 to 16 (series 2, municipal wastewater with flowback water); these differences were not significant (Kruskal-Wallis test, $p=0.1654$ ). The total microfauna abundance without small flagellate species varied from 10,040 to 21,000 organisms $/ \mathrm{cm}^{3}$ in series 1 , and from 14,640 to 32,080 organisms $/ \mathrm{cm}^{3}$ in series 2; the mean microfauna abundance differed significantly between the series (Kruskal-Wallis test, $p=0.0157$ ). During the study, the number of small flagellates counted along the diagonal of a Fuchs-Rosenthal chamber did not exceed 9 individuals.

In the 26 analyzed samples, 22 taxa of microfauna were identified, including 2 flagellates, 12 ciliates, 2 naked amoebae, 3 shelled amoebae, rotifers and tardigrades. In the all samples, there were found small flagellates, the ciliates Aspidisca cicada, Vorticella infusionum, Vorticella convalaria, Carchesium polypinum and the shelled amoebae Arcella vulgaris (Table 3 ). In series 1 , the following taxa were significantly more abundant: the crawling ciliate Euplotes affinis, the attached ciliates Vorticella convallaria and Epistylis plicatilis and the rotifer Philodinidae. In series 2, the flagellate Peranema trichophorum, the swimming ciliate Enchelyomorpha vermicularis, the testate amoeba Arcella vulgaris, 
and tardigrades were significantly more abundant (Kruskal-Wallis test, $p<0.005$ ). The average abundance of other taxa did not differ significantly between series 1 and 2 (Table 3).

Table 3

Frequency of occurrence and abundance of protozoa and small metazoa during the study; $n$ - number of samples; \pm - standard deviation; $P$ - probability of $\mathrm{H}_{0}$ (series 1 - wastewater treatment, series 2 - wastewater with flowback water treatment)

\begin{tabular}{|c|c|c|c|c|c|c|}
\hline \multirow{2}{*}{$\begin{array}{c}\text { Functional } \\
\text { groups }\end{array}$} & \multirow[b]{2}{*}{ Taxons } & \multicolumn{2}{|c|}{ Series $1 ; n=8$} & \multicolumn{2}{|c|}{ Series $2 ; n=18$} & \multirow[b]{2}{*}{$P$-Value } \\
\hline & & $\begin{array}{c}\text { Frequency } \\
{[\%]}\end{array}$ & \begin{tabular}{|l|} 
Abundance \\
{$\left[\right.$ ind. $\cdot \mathbf{c m}^{-3}$ ] }
\end{tabular} & $\begin{array}{c}\text { Frequency } \\
{[\%]}\end{array}$ & $\begin{array}{l}\text { Abundance } \\
{\left[\text { ind. } \cdot \mathbf{c m}^{-3} \text { ] }\right.}\end{array}$ & \\
\hline \multirow[b]{2}{*}{ Flagellates } & Flagellates $<20 \mu \mathrm{m}$ & 100 & $* 4 \pm 3$ & 100 & $* 3 \pm 2$ & 0.9574 \\
\hline & $\begin{array}{c}\text { Peranema } \\
\text { trichophorum }\end{array}$ & 50 & $50 \pm 73$ & 100 & $345 \pm 280$ & 0.0058 \\
\hline \multirow{4}{*}{$\begin{array}{l}\text { Crawling } \\
\text { ciliates }\end{array}$} & Aspidisca cicada & 100 & $5130 \pm 4670$ & 100 & $2650 \pm 2100$ & 0.6744 \\
\hline & Euplotes affinis & 100 & $215 \pm 140$ & 75 & $80 \pm 80$ & 0.0381 \\
\hline & Acineria uncinata & 75 & $175 \pm 200$ & 50 & $235 \pm 220$ & 0.7873 \\
\hline & $\begin{array}{c}\text { Chilodonella } \\
\text { uncinata }\end{array}$ & 50 & $350 \pm 380$ & 50 & $246 \pm 370$ & 0.6536 \\
\hline \multirow{4}{*}{$\begin{array}{l}\text { Attached } \\
\text { ciliates }\end{array}$} & Vorticella infusionum & 100 & $380 \pm 270$ & 100 & $870 \pm 560$ & 0.0827 \\
\hline & $\begin{array}{c}\text { Vorticella } \\
\text { convallaria } \\
\end{array}$ & 100 & $310 \pm 170$ & 100 & $125 \pm 62$ & 0.0128 \\
\hline & $\begin{array}{l}\text { Carchesium } \\
\text { polypinum }\end{array}$ & 100 & $1625 \pm 1100$ & 100 & $1270 \pm 920$ & 0.5621 \\
\hline & Epistylis plicatilis & 100 & $1215 \pm 1000$ & 75 & $386 \pm 340$ & 0.0515 \\
\hline \multirow{3}{*}{$\begin{array}{l}\text { Carnivorous } \\
\text { ciliates }\end{array}$} & $\begin{array}{c}\text { Tokophrya } \\
\text { quadripartita }\end{array}$ & 25 & $15 \pm 30$ & 25 & $15 \pm 90$ & 1.00 \\
\hline & Holophrya discolor & 75 & $65 \pm 56$ & 75 & $125 \pm 170$ & 0.7080 \\
\hline & Litonotus lamella & 25 & $15 \pm 30$ & 50 & $35 \pm 54$ & 0.3607 \\
\hline $\begin{array}{l}\text { Swimming } \\
\text { ciliates }\end{array}$ & $\begin{array}{c}\text { Enchelyomorpha } \\
\text { vermicularis }\end{array}$ & 50 & $575 \pm 640$ & 100 & $1640 \pm 920$ & $\mathbf{0 . 0 3 9 0}$ \\
\hline \multirow{2}{*}{$\begin{array}{c}\text { Naked } \\
\text { amoebae }\end{array}$} & Acanthamoeba sp. & 75 & $250 \pm 340$ & 100 & $75 \pm 33$ & 0.7880 \\
\hline & Mayorella sp. & 50 & $45 \pm 54$ & 50 & $25 \pm 30$ & 0.5710 \\
\hline \multirow{3}{*}{$\begin{array}{c}\text { Shelled } \\
\text { amoebae }\end{array}$} & Arcella vulgaris & 100 & $3300 \pm 670$ & 100 & $\begin{array}{c}13740 \pm \\
5900\end{array}$ & 0.008 \\
\hline & Cochliopodium sp. & 50 & $160 \pm 220$ & 75 & $290 \pm 260$ & 0.2794 \\
\hline & Euglypha leavis & 50 & $20 \pm 21$ & 75 & $70 \pm 60$ & 0.0758 \\
\hline \multirow{2}{*}{ Rotifers } & Lecanidae & 100 & $145 \pm 180$ & 50 & $50 \pm 63$ & 0.1320 \\
\hline & Philodinidae & 100 & $130 \pm 110$ & 75 & $40 \pm 30$ & 0.0166 \\
\hline Tardigrada & Tardigrada n.det & 25 & $10 \pm 19$ & 75 & $45 \pm 33$ & 0.0296 \\
\hline
\end{tabular}

*number of flagellates counted along the Fuschs-Rosenthal chamber diagonal

Observed microfauna consisted of taxa belonging to positive keygroups [11]. The predominance of shelled amoeba, crawling ciliates and attached ciliates with wide peristomes and the fact that tardigrades and rotifers were commonly found both indicated a healthy, low-loaded, sufficiently aerated and well-flocculated activated sludge that would produce high quality effluent [21-26]. The sludge biotic index (SBI), calculated on the basis of the microfauna composition in samples, was always the highest value possible (10/10). The high value of the SBI indicates the high quality of the activated sludge and a stable, very well inhabited microfauna, with high biological activity and high treatment effectiveness. 
The low concentrations of chemical indicators in treated wastewater confirmed the results of the biological analysis. However, as can be seen in Figure 1, the relative abundance of the microfauna taxa changed with the addition of flowback water. In series 1 , crawling ciliates predominated. In series 2, with flowback water, testate amoebae predominated to a greater extent. The diversity of protozoa was significantly higher in series $1(\mathrm{H}=1.907$ its/ind.) than in series $2(\mathrm{H}=1.468$ its/ind.) (t-test; $p=0.0000)$; this difference was connected with the increase in abundance of the shelled amoeba Arcella vulgaris. A well-functioning system has highly diversified microfauna composed of different groups of organisms. No group or species is ever dominant over the others, even if the ratios between various groups or species differ. In contrast, microfauna that is dominated by one group indicates a trophic imbalance caused by limiting factors that impede the development of other species [27].

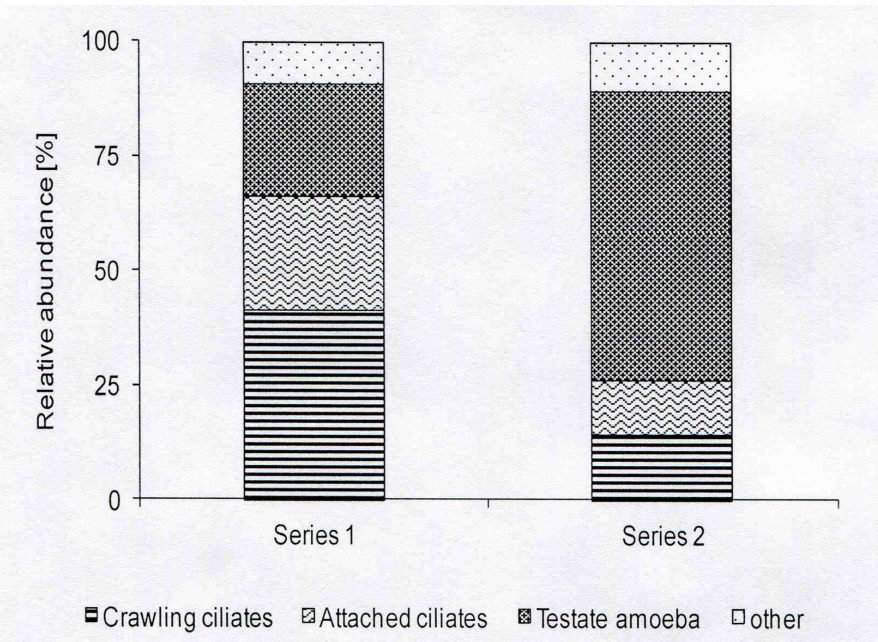

Fig. 1. Relative abundance of functional groups of microfauna during the study; series 1 - wastewater treatment, series 2 - wastewater with flowback water treatment

In this study, flowback water was added to treated wastewater for only 9 weeks. Over a longer period of time, such a decrease in protozoa biodiversity may lead to deterioration in the efficiency of wastewater treatment as high biodiversity among the protozoan population is fundamental for reaching high plant performance [28].

\section{PCR-DGGE analysis of total bacterial community and ammonia oxidizers in activated sludge}

In order to o assess the changes in the microbial community implemented by the addition of flowback water PCR-DGGE analysis was performed as a screening method.

The composition of the total bacterial community was analyzed with 16S rRNA partial gene amplified with $338 \mathrm{f}-\mathrm{GC}$ and $518 \mathrm{r}$ primers. AOB community was monitored with ammonia monooxygenase gene partial sequence. Samples for PCR-DGGE monitoring were collected from series 1 of the experiment (when the system was treating municipal wastewater; control sample at time 0) and from series 2 (when the system was treating 
mixture of wastewater with flowback water; between 4 to 12 week of the experiment) at two-week intervals to present the changeability of bacterial patterns. Total sample number was 5 .

AmoA

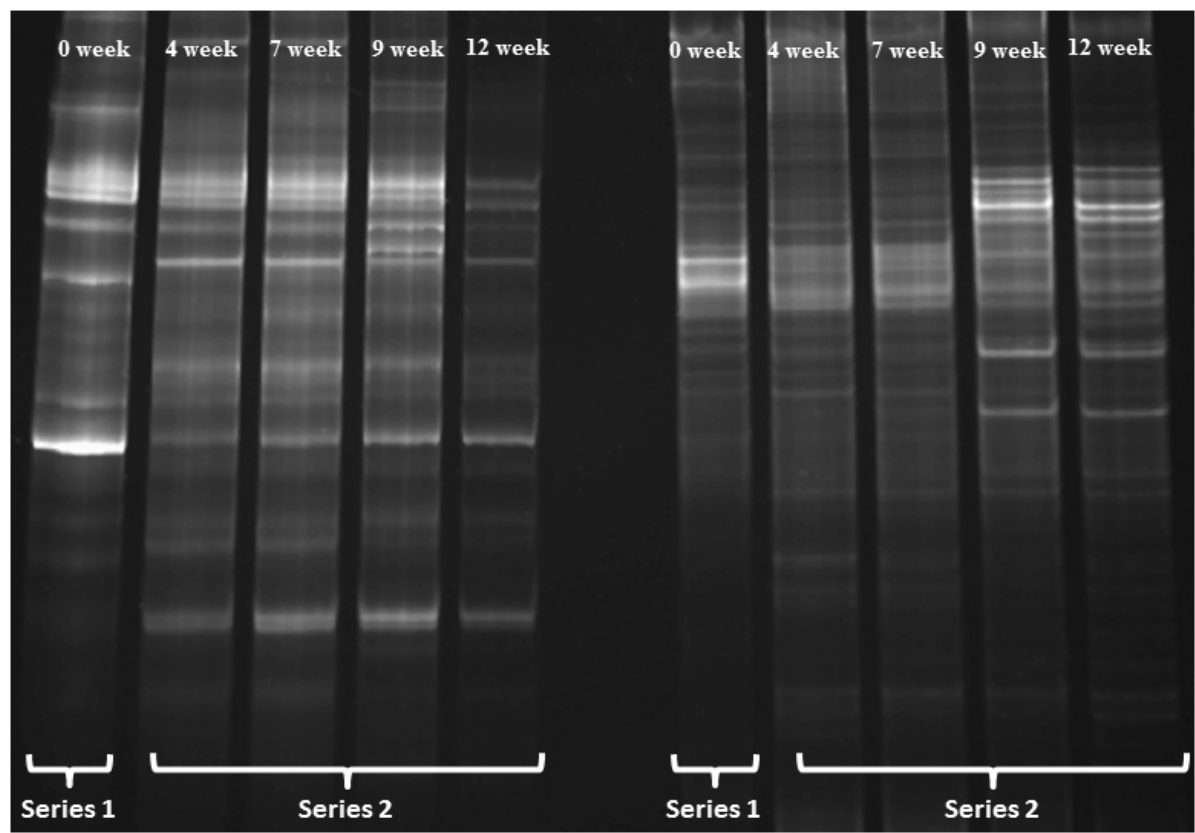

Fig. 2. PCR-DGGE-based genotypic structure of activated sludge bacterial community during the study; AmoA - AOB analysis based on ammonia monooxygenase sequence; 16S rRNA gene - total community monitoring based on $16 \mathrm{~S}$ rRNA gene sequence; series 1 - wastewater treatment, series 2 - wastewater with flowback water treatment

As it is presented in Figure 2 total bacterial community did not respond immediately after flowback water introduction. The community change is observed in series 2 after $7^{\text {th }}$ week of the experiment (two weeks after flowback water addition to the wastewater). In the beginning the community was composed with relatively high number of genotypes without any dominant DNA bands. Such situation seems to be common for bacterial monitoring in activated sludge of municipal WWTPs with these primers [14]. That is why the samples monitored with PCR-DGGE are divided into two series - sample at time 0 as control, when no visible changes were observed in activated sludge bacterial community and in series 2 where samples were collected at 2 week interval to present community changeability. The composition of samples collected in series 2 at $9^{\text {th }}$ and $12^{\text {th }}$ week of the experiment changed. Several stronger bands in the higher part of the gel appeared. AT rich genotypes become dominant in the biocenosis while GC rich genotypes were not visible in such strength as in the beginning of the experiment. As it has been expected, the AOB community composition changed directly after flowback water addition (series $2,4^{\text {th }}$ week of the experiment). Interestingly, the fingerprint composition for the AOB community was maintained during 
the period of flowback water implementation. Such results suggests, that despite a quick response to flowback water implementation changing the AOB community structure the biocenosis remains stable during these wastewater treatment probably because of the relatively low content of flowback water in the wastewater. AOB community responds faster that total bacterial community, but in the same time the changes are less drastic.

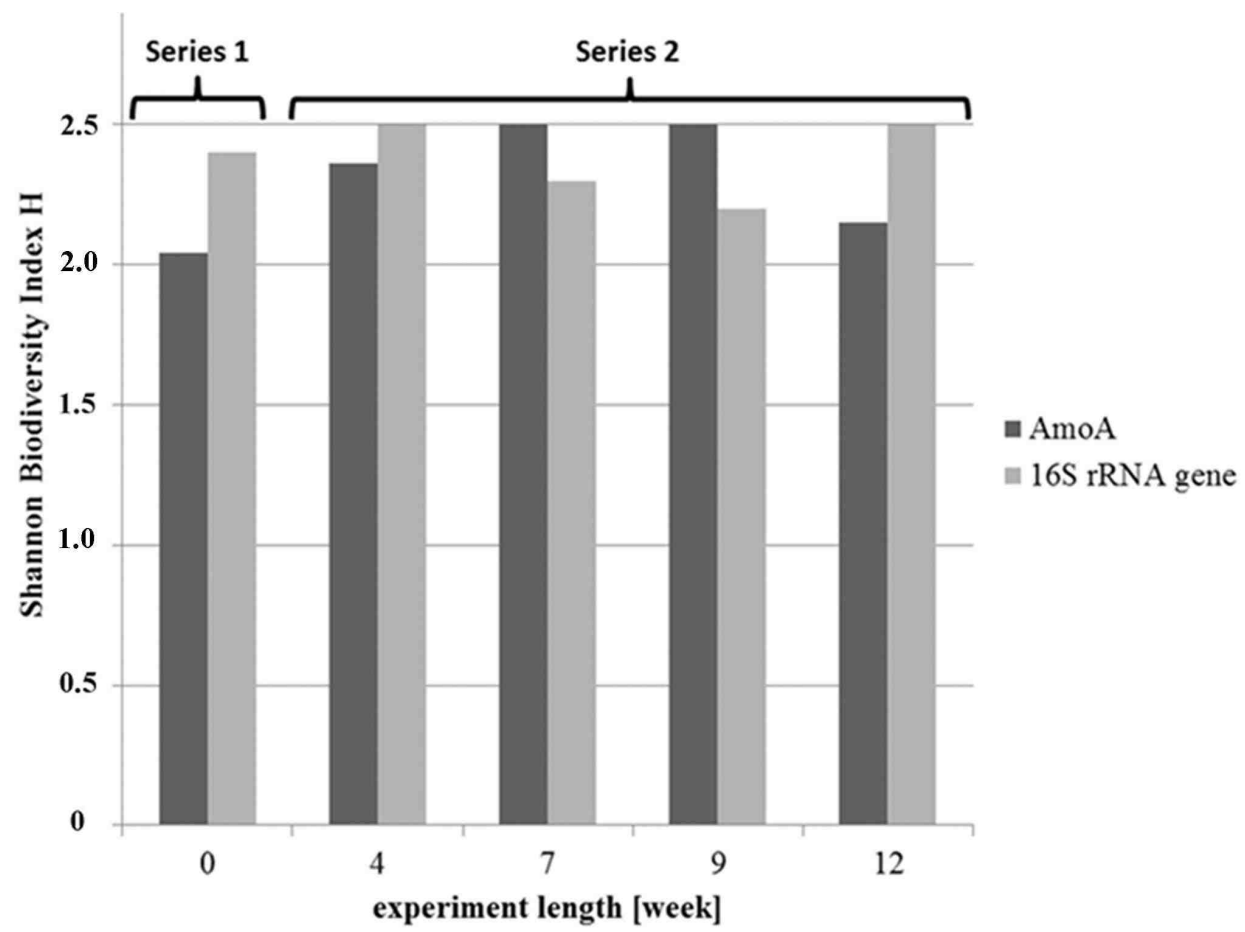

Fig. 3. Shannon Biodiversity Index $(\mathrm{H})$ calculated on the basis of PCR-DGGE analysis of bacterial community in activated sludge during the study; AmoA - AOB analysis based on ammonia monooxygenase sequence; $16 \mathrm{~S}$ rRNA gene - total community monitoring based on 16S rRNA gene sequence; series 1 - wastewater treatment, series 2 - wastewater with flowback water treatment

Shannon biodiversity index was increasing for both, AmoA and 16S rRNA gene based monitoring in the beginning of the experiment, directly after flowback water implementation to the system (Fig. 3). Total bacterial biodiversity was calculated on the basis of 16S rRNA partial gene sequence. It was higher in the sample collected before flowback water addition (time 0$)$ and directly after its implementation $\left(4^{\text {th }}\right.$ week of the experiment). The biodiversity begin to decrease on the $7^{\text {th }}$ week of the experiment, in the same time when the qualitative community change on DGGE is visible (Fig. 2). On the contrary to the total bacterial community the AOB biodiversity was increasing constantly after flowback water addition and decreased after 9 weeks of the experiment when biodiversity of total bacterial community seems to be restored. This situation could suggest that prolonged exposition to flowback water has negative influence on nitrifiers in activated sludge. These results 
underline that biodiversity indexes should be analyzed together with the qualitative changes of DGGE fingerprints to present the total picture of bacteria community because not all qualitative changes of the community are visible on biodiversity indexes changes.

\section{Conclusions}

Chlorides, organics and nitrogen were the main pollutants in the flowback water used in this study, which contained low concentrations of metals and suspended solids. Thus, introducing flowback water to the WWTP in amounts up to 5\% did not decrease the quality of effluent. However, this was accompanied by changes in activated sludge microfauna a decrease in the biodiversity of protozoa which indicated trophic imbalance. Molecular analysis showed that the ammonia oxidizers community responded faster to flowback water addition than the total bacterial community; this was seen as a qualitative change in the biocenosis. The AOB community remained relatively stable during flowback water treatment, but its biodiversity began to decrease after 9 weeks of treatment. This suggests that longer exposition to flowback water probably cause nitrification problems, leading to deterioration of effluent quality during prolonged co-treatment of municipal wastewater with flowback water. Therefore, further studies are needed to analyze changes in pollutant concentrations during the SBR cycle (kinetic studies of pollutants removal) to allow more in-depth understanding of the long-term effects of flowback water on WWTP efficiency.

\section{Acknowledgements}

This work was supported by project No. 528-0803-0805, financed by University of Warmia and Mazury in Olsztyn, Poland.

\section{References}

[1] Vidic RD, Brantley SL, Vandenbossche JM, Yoxtheimer D, Abad JD. Impact of shale gas development on regional water quality. Science. 2013;340:6134. DOI: 10.1126/science.1235009.

[2] Waxman HA, Markey EJ, DeGette D. Chemicals used in Hydraulic Fracturing House of Representatives Committee of Energy and Commerce Minority Staff U.S.; 2011. http://conservationco.org/admin/ wp-content/uploads/2013/02/Final-Rebuttal-Exhibits.pdf-Adobe-Acrobat-Pro.pdf

[3] Colborn T, Kwiatkowski C, Schultz K., Bachran M. Natural gas operations from a public health perspective. Hum Ecol Risk Asses. 2011;17:1039-1056. DOI: 10.1080/10807039.2011.605662.

[4] Olsson O, Weichgrebe D, Rosenwinkel K-H. Hydraulic fracturing wastewater in Germany: composition, treatment, concerns. Environ Earth Sci. 2013;70:3895-3906. DOI: 10.1007/s12665-013-2535-4.

[5] Fakhru'l-Razi A, Pendashteh A, Abdullah LC, Biak DRA, Madeani SS, Abidin ZZ. Review of technologies for oil and gas produced water treatment. J Hazard Mater. 2009;170/2:530-551. DOI: 10.1016/j.jhazmat.2009.05.044.

[6] Liu J, Yang M, Qi R, An W, Zhou J. Comparative study of protozoan communities in full-scale MWTPs in Beijing related to treatment processes. Water Res. 2008;42:1907-1918. DOI:10.1016/j.watres.2007.11.020.

[7] Jiang Q, Rentschler J, Perrone R, Liu K. Application of ceramic membrane and ion-exchange for the treatment of the flowback water from Marcellus shale gas production. J Membrane Sci. 2013;431:55-61. DOI: 10.1016/j.memsci.2012.12.030.

[8] Greenberg AE, Clesceri LS, Eaton AD, Standard Methods for the Examination of Water and Wastewater. Washington: APHA; 1992.

[9] Foissner W, Berger H, A user-friendly guide to the Ciliates (Protozoa, Cliophora) commonly used by hydrobiologists as bioindicators in rivers, lakes, and waste waters, with notes on their ecology. Freshwater Biol. 1996;35:375-482. DOI: 10.1111/j.1365-2427.1996.tb01775.x 
[10] Curds CR, Warren A, Salvado Cabre H, Roberts D. An Atlas of Ciliated Protozoa Commonly Found in Aerobic Sewage-Treatment Processes. An Aid to Monitor Treatment-Plant Performance. London: Natural History Museum; 2008.

[11] Madoni P. A sludge biotic index (SBI) for the evaluation of the biological performance of activated sludge plants based on microfauna analysis. Water Res. 1994;28:67-75. DOI: 10.1016/0043-1354(94)90120-1.

[12] Muyzer G, De Waal EC, Uitierlinden AG. Profiling of complex microbial populations by denaturing gradient gel electrophoresis analysis of polymerase chain reaction-amplified genes coding for 16S rRNA. Appl Environ Microbiol. 1993;59:695-700. DOI: 0099-2240/93/030695-0602.00/0.

[13] Rotthauwe JH, Witzel KP, Liesack W. The ammonia monooxygenase structural gene amoA as a functional marker: molecular fine-scale analysis of natural ammonia-oxidizing populations. Appl Environ Microbiol. 1997;63:4704-4712. DOI: 0099-2240/97/04.00.

[14] Ziembińska A, Ciesielski S, Miksch K. Ammonia oxidizing bacteria community in activated sludge monitored by denaturing gradient gel electrophoresis (DGGE), J Gen Appl Microbiol. 2009;55:375-380. DOI:10.2323/jgam.55.373.

[15] Magurran AE. Ecological Diversity and its Measurement. Cambrige: University Press; 1988.

[16] Olsson O, Weichgrebe D, Rosenwinkel KH. Hydraulic fracturing: Zusammensetzung und entsorgung anfallender abwässer (Hydraulic fracturing: composition and disposal of incurred wastewater). Wasser Abfall. 2012;14(9):10-15. DOI: 10.1007/s12665-013-2535-4.

[17] Jiang Q, Rentschler J, Perrone R, Liu K. Application of ceramic membrane and ion-exchange for the treatment of the flowback water from Marcellus shale gas production. J Membrane Sci. 2013;431:55-61. DOI: 10.1016/j.memsci.2012.12.030.

[18] Miller DJ, Huang X, Li H, Kasemset S, Lee A, Agnihotri D, et al. Fouling-resistant membranes for the treatment of flowback water from hydraulic shale fracturing: A pilot study. J Membrane Sci. 2013;437:265-275. DOI: 10.1016/j.memsci.2013.03.019.

[19] Zdybek I. Wpływ jonów chlorkowych na efektywność biologicznej defosfatacji ścieków. (Effect of chloride ions on the efficiency of enhanced biological phosphorus removal from wastewater) Ochr Środow. 2005;27(2):13-17.

[20] Uygur A, Kargi F. Salt inhibition on biological nutrient removal from saline wastewater in a sequencing batch reactor. Enzyme Microb Technol. 2004;34:313-318. DOI: 10.1016/j.enzmictec.2003.11.010.

[21] Drzewicki A, Kulikowska, D. Limitation of sludge biotic index application for control of wastewater treatment plant working with shock organic and ammonium loadings. Eur J Protistol 2011;47:287-294. DOI: 10.1016/j.ejop.2011.06.001

[22] Pérez-Uz B, Arregui L, Calvo P, Salvadó H, Fernández N, Rodríguez E, et al. Assessment of plausible bioindicators for plant performance in advanced wastewater treatment systems. Water Res. 2010;44:5059-5069. DOI: 10.1016/j.watres.2010.07.024

[23] Zhou K, Xu M, Liu B, Cao H. Characteristics of microfauna and their relationships with the performance of an activated sludge plant in China. J Environ Sci. 2008;20:482-486. DOI:10.1016/S1001-0742(08)62083-5.

[24] Tyagi VK, Subramaniyan, S, Kazmi AA, Chopra AK., Microbial community in conventional and extended aeration sludge plants in India. Ecol Ind. 2008;8:550-554. DOI: 10.1016/j.ecolind.2007.07.002.

[25] Chen S, Xu M, Cao H, Zhu J, Zhou K, Xu J, et al. The activated sludge fauna and performance of five sewage treatment plants in Beijing, China. Eur J Protistol. 2004;40:147-152. DOI: 10.1016/j.ejop.2004.01.003.

[26] Lee S, Basu S, Tyler CW, Wei IW. Ciliate populations as bio-indicators at Deer Island treatment plant. Adv Environ Res. 2004;8:371-378. DOI: 10.1016/S1093-0191(02)00118-1.

[27] Madoni P., Protozoa in wastewater treatment processes: A mini review. Ital J Zool. 2011;78:3-11. DOI:10.1080/11250000903373797.

[28] Tocchi C, Federici E, Fidati L, Manzi R, Vincigurerra V. Aerobic treatment of dairy wastewater in an industrial three-reactor plant: Effect of aeration regime on performances and protozoan and bacterial communities. Water Res. 2012;46:3334-3344. DOI: 10.1016/j.watres.2012.03.032. 


\title{
WPEYW WÓD PO SZCZELINOWANIU HYDRAULICZNYM NA BIOCENOZE OSADU CZYNNEGO PODCZAS OCZYSZCZANIA ŚCIEKÓW MIEJSKICH
}

\author{
${ }^{1}$ Katedra Biotechnologii Środowiskowej, Politechnika Śląska, Gliwice \\ ${ }^{2}$ Katedra Turystyki, Rekreacji i Ekologii, Uniwersytet Warmińsko-Mazurski w Olsztynie \\ ${ }^{3}$ Katedra Biotechnologii w Ochronie Środowiska, Uniwersytet Warmińsko-Mazurski w Olsztynie
}

\begin{abstract}
Abstrakt: Celem badań była ocena wpływu wód po szczelinowaniu hydraulicznym na biocenozę osadu czynnego podczas oczyszczania ścieków miejskich w reaktorach SBR. Przeprowadzono 2 serie badawcze. W serii 1, kontrolnej, oczyszczano ścieki miejskie, w serii 2 - ścieki miejskie z dodatkiem wód po szczelinowaniu. Udział wód, które wprowadzano dwa razy w tygodniu, stanowił 3-5\% objętości doprowadzanych ścieków. Wykazano, że wprowadzenie wód nie miało wpływu na jakość ścieków oczyszczonych, ale spowodowało spadek różnorodności biologicznej pierwotniaków i zmiany w strukturze dominacji grup funkcyjnych. Zastosowanie metody PCR-DGGE pozwoliło na wykazanie, że struktura genotypowa zbiorowiska bakterii nitryfikacyjnych I fazy zmieniała się szybciej niż całość biocenozy bakteryjnej osadu czynnego i była stosunkowo stała w trakcie trwania eksperymentu. Odnotowano, że po 9 tygodniach eksperymentu nastąpiło zubożenie różnorodności bakterii nitryfikacyjnych I fazy. Uzyskane wyniki sugerują, że dłuższa ekspozycja mikroorganizmów osadu czynnego na wody po szczelinowaniu hydraulicznym może prowadzić do obniżenia efektywności nitryfikacji, a w dalszej konsekwencji do pogorszenia jakości odpływu.
\end{abstract}

Słowa kluczowe: wody po szczelinowaniu hydraulicznym, SBR, mikrofauna osadu czynnego, zbiorowisko nitryfikatorów I fazy, PCR-DGGE 